DOI 10.18551/rjoas.2019-12.33

\title{
CONVENTIONAL SOCIAL INSTITUTION SUPPORTING FINANCIAL SUSTAINABILITY OF AGRICULTURAL COMMUNITIES
}

\author{
Pertiwi Vi'in Ayu \\ Faculty of Agriculture, University of Brawijaya, Malang, Indonesia \\ E-mail: viinayu@ub.ac.id
}

\begin{abstract}
This research was motivated by the weakness of financial capital of chilli farmers who cannot afford the cost of their chilli farming. Furthermore, for making the business still give an enough profit, they sell their products to middlemen. In here, there are the uniqueness relationship between chilli farmers and middlemen. Based on farming needs and the relationship established between farmers and middlemen, social institutions are created. This study aimed to determine the institutional system or social institutions between chilli farmers and middlemen in Tegalweru Village, Malang Regency, Indonesia. This research employed a qualitative method approach with a case study research design where data were collected by indepth interview with farmers and middlemen in the Tegalweru Village. Results showed that there are institutional system in the farmer community, such as wage system, land rent, and partnership system in terms of buying and selling agricultural products and even in nonfarming sector. Farmers get their financial capital from middlemen. Then, they will pay it when their products are sold by middlemen. In short, middlemen are the one who have the power to provide financial capital that accessible for the sustainability of financial capital in chilli business.
\end{abstract}

\section{KEY WORDS}

Social support, institutions, capital, sustainability, financial system, chilli.

Commercial agriculture has become a rural agricultural culture in Indonesia. The development of commercial agriculture as a form of natural wealth's distribution in rural areas maintains the food security in rural communities. Commercialization of agriculture certainly has varieties of impact such as the emergence of socio-economic disparities in agricultural communities in the village. Rustinsyah (2011) stated that the existence of inequality in socioeconomic, market, and capital causes patron-client relationship among farmers. The emergence of a patron-client relationship between farmers and middlemen is clearly the impact of the commercialization and modernization of agriculture in the countryside. Geertz in De Cunzo (2004) said that middlemen as intermediary creates an effective point between farmers, traditional cultural patterns and metropolitan life, and modern cultural patterns. The middleman is formed from the commercialization of agriculture so that he becomes an intermediary between farmers in order to accustom an agricultural modernization.

The middleman has directly relationship with the farmers because farmers do not sell their products to the market or final consumers. This case happens because the middlemen usually take agricultural products from farmers in large quantities. Narrow farmer land ownership also supports this case. BPS (2018) stated that Indonesian agricultural land is narrow which less than 0.5 hectare per farm household. This fact arise the role of middlemen as traditional institutions to deliver agricultural products from farmers to consumer. The middlemen also play a role to provide the financial capital of farmers in farming cost and even in family living cost when they need by urgent. Client usually has positive benefits in terms of loans for subsistence security or even for investment purposes, flexibility of its repayment periods, protection when facing difficulties, providing production facilities, legal protection, increasing access to markets, personal support, and increasing access to various resources and information (Ferrol et al, 2014). Patrons has benefits to cover client loyalty, availability of labor, increasing prestige in the community, providing information related to competitors, supporting local politics, and reducing production costs. 
The institutional system between traditional farmers and middlemen does not only occur in villages that are far from urban access and far from competitive markets but also in villages that are close to urban areas and close to markets. The traditional institution system still plays an important role in agricultural products marketing in Tegalweru Village Malang Indonesia that close to urban areas. There are a lot of farmers in Tegalweru Village who prioritize to cultivate chili, even though chili has a fluctuative price. This is supported by the presence of middlemen who are willing to accept the chili crops. Prior research has focused more on relationship between client and middlemen (Rustyansah, 2011; Syaputra, 2018). However, an interesting phenomenon between farmers and middlemen in Tegalweru Village led researchers to focus more on the sociological perspective in the institutional system that happens between farmers and middlemen in Tegalweru Village, Malang Regency, Indonesia.

\section{METHODS OF RESEARCH}

This study used a qualitative approach. Qualitative research can be interpreted as research that aim to understand phenomena about something experienced by the object of research holistically, then it is described by the form of word and language in natural contexts by utilizing various scientific methods (Moleong, 2016). This research employed a study case design. The study case design is used to explain a case in full and in depth where the research will focus on the question "how and why" (Plano \& Creswell, 2015). The design of this case study is used to understand deeply the relationship between farmers and middlemen at the research location and the institutional system/social institutions that has been run by farmers and middlemen.

Data were collected by in-depth interview, observation, and documentation towards farmers and middlemen chilli in Tegalweru Village, Malang Regency, Indonesia. The informants were selected using snowball sampling technique. The process of selecting informants is based on prior informants without determining the exact number of informants.

The study was conducted in Tegalweru Village as one of the villages in Malang, Indonesia which is close to urban areas but still has good agricultural potential crops and the majority of the population is farmers and has relationship with middlemen. Moreover, considering that farmers have limited financial capital so that the credit institutions that can fulfill it is traditional credit institutions called "juragan".

This study used qualitative data analysis namely the Miles and Huberman techniques. As stated by Miles and Huberman (2014) that the analysis of qualitative data is an ongoing, repeated and continuous effort. This study used "Analysis Interactive Model" from Miles and Huberman to analyze the data. Data were analyzed by four main steps, data collection, data reduction, data display, and verification or conclusions.

\section{RESULTS AND DISCUSSION}

According to Planck (1993), social institutions are defined as a way that regulates how an activity is carried out. Social institutions are formed from human needs. Social institutions include a system of thinking patterns and behavior patterns that are manifested through community activities that aim to fulfill the needs of the community. As stated by Soukup (2016), institutions are impartial and crucial elements of the social reality and concentrate on institutions belonging to the categories of Individuals to Institutions, Systems and Explicit existence. Therefore, it forms a social institutions system in Tegalweru Village, especially in the chili farmers' community because of the needs of providing production to marketing chili. Chili is a seasonal horticultural commodity where farmers can harvest it every season. The relationship of farmers with middleman or "juragan" on the chili agribusiness system is shown in Figure 1.

The need of farmers in labor and food causing some farmers work as labor in agriculture beside as land providers. The yields of agricultural production are sold to middlemen or middleman. Middleman also has a role as a provider of capital to farmers in the form of money and the other agricultural input needs. As explained by Sudarta (2016), 
the need for food and labor in the village produces a system for regulating the distribution of food and labor, for example the existence of a wage system, a land rent system, etc. In addition, the form of institutions or social institutions in terms of money produces an economic system such as pawn system, buying and selling, credit system, etc.

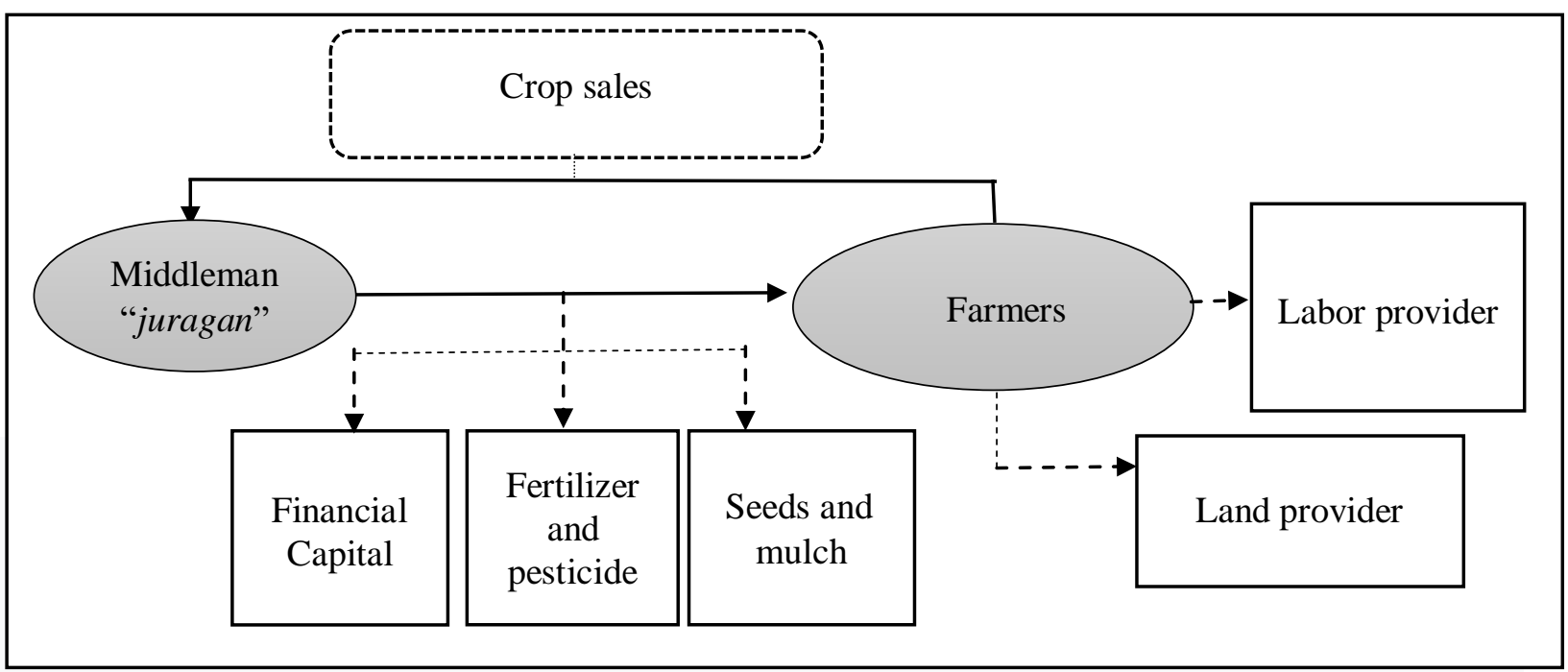

Figure 1 - Relationship between farmers and middleman in the chili agribusiness system in Tegalweru Village, Malang, Indonesia

The social institutions system that exists in chili farming in Tegalweru Village, Malang Regency, are the wage system for payment of labor, the system of renting land to provide agricultural land, the system of partnership between farmers and middleman in terms of capital loan and marketing of the crops.

The system of wage social institutions was born from the agriculture commercialization because of the need of labor. The non-functional mutual cooperation system "gotong royong" among community makes labor wage system has arouse. The number of labors that has been declining in Tegalweru Village makes their wages is higher. Chili farm labors have a problem in the age of labor which is over the productive age. The average age of chilli farmers in Tegalweru village are above 50 years. It was made clear by BPS (2018) that the productive age of labors start at 15 years old. Heavy working conditions with too old age cause unproductive work. This is supported by the description of structural changes in the demographic workforce in the agricultural sector. According to Susilowati (2016), declining the number of young farmers is closely related to the narrow ownership of agricultural land and general perceptions of the agricultural sector which is less prestigious and does not provide a good income.

Farmers get labor from their neighbors by offering them and give them wage. According to Sukirno (2005), wage is defined as payments or remuneration both physically and mentally provided by labors to employers. The labor wage system in Tegalweru Village is a daily system. The daily system is a wage labor system that is given per day and per person by calculating how much work time per day. Wage for workers on chilli farming vary depending on what work is done and who does it. This wage system is nominally determined by the owner's land from market price information in the village and by offering from the labor. Wages for male labor for every half day (5 hours of work from 05.00 - 10:00 or 07.00 12.00 depending on what work is done) range from $\mathrm{Rp} \mathrm{40,000}$ to $\mathrm{Rp} 50,000$, while the wages of female workers per half a day are Rp. 35,000 - up to Rp. 40,000, - depending on whether the work is heavy or not. According to the agreement, labor costs usually has included food costs, but farmers still often bring snacks (cakes) and tea or drink for labor on land. So that in the economic behavior of farmers is still bound by social behavior for maintaining good relationship with labor. As stated by Sytch, et al (2013) that economic action and social 
relations are closely intertwined where on one side the economic system is embedded in the social system. So that economic action cannot be separated from social behavior.

Farmers as a middleman partner are obliged to provide land for chilli farming. As stated by Susanti et al (2013), temporary agricultural land splits has occurred because one of them is the existence of land leasing institutions. The land leasing system still applies in the Tegalweru Village to those who do not have their own land or to those who wants to add an arable land, as farmers who rent agricultural land in the Tegalweru Village started of $R p$ $7.500 .000,-/ h a / y e a r$. The price applies according to the agreement for how many years the land is leased. However, those prices are increasingly rising along with the high demand for land both for agriculture and settlements that are growing in the Tegalweru Village area. Farmers usually rent land to plant chili because chili is short-lived and can be harvested immediately. As stated by Hardono (1992), the increasing population causes alteration in the system of land tenure, one of which is the land rent system which is increasing in price and value.

One of the institutional forms of the relationship between farmers and chili middleman in Tegalweru Village is the establishment of a partnership system between chili farmers and middleman who become a provider of capital and a buyer of crops. Based on (Fig 1) shows that the farmers with make a partnership with the middleman in the KOA (Agribusiness Operational Cooperation) system. This pattern of this cooperation is found in many rural communities especially to meet the needs of farmers in the village. As explained by Saptana and Ashari (2007), there are several patterns of business partnerships in the agribusiness system in Indonesia that will guarantee the sustainability of farmer agribusiness businesses, one of which is the agribusiness operational partnership (KOA) pattern. Middleman as the capital provider, provider of inputs for farming starts from financial capital, capital of production facilities such as fertilizers, pesticides, mulch and seeds. In addition, farmers partner with middleman as a supplier of agricultural products to be marketed by middleman.

Table 1 - Things are considered in the partnership between farmers and middleman in Tegalweru Village, Malang Regency, Indonesia

\begin{tabular}{|c|c|}
\hline Farmers & Middlemen \\
\hline $\begin{array}{l}\text { The right to get a capital loan farming from the } \\
\text { middleman; } \\
\text { The right to grow chili by farmer; } \\
\text { Get a capital loan for the next season if there are failure } \\
\text { in certain season; } \\
\text { The right to get revenue from the crops after the } \\
\text { farmers' loans are deducted }\end{array}$ & $\begin{array}{l}\text { The right to get agricultural products from farmers who } \\
\text { have been given financial capital farming; } \\
\text { Give punishment by not giving capital to farmers if they } \\
\text { don't sell their harvest to the middleman; } \\
\text { The right to determine the price of chillies purchased } \\
\text { from farmers; } \\
\text { Receive back the capital that has been lent to farmers }\end{array}$ \\
\hline $\begin{array}{l}\text { Provide agricultural land; } \\
\text { Provide labor; } \\
\text { Obligation of farmers to sell agricultural products to } \\
\text { those who lend financial capital; } \\
\text { Paying the debt that has been borrowed from the } \\
\text { middleman }\end{array}$ & $\begin{array}{l}\text { The obligation to provide financial capital loans and } \\
\text { production facilities such as fertilizers, pesticides, } \\
\text { mulch and seeds to farmers for each planting season; } \\
\text { Buy partner farmers' crops }\end{array}$ \\
\hline $\begin{array}{l}\text { Get farming capital; } \\
\text { Interest-free capital (not like a bank); } \\
\text { Get market; } \\
\text { The easier process of capital loan }\end{array}$ & $\begin{array}{l}\text { Obtain relationships or certainty suppliers of } \\
\text { agricultural commodities; } \\
\text { Get a supply of products at prices according to the } \\
\text { middleman's wishes; } \\
\text { profit/price differences obtained more }\end{array}$ \\
\hline $\begin{array}{l}\text { Break the agreement with the middlen } \\
\text { agricultural commodities to other middlen }\end{array}$ & Provide prices below market prices \\
\hline
\end{tabular}

Chili horticulture farming requires a lot of capital. Even chili farmers need millions of capital per hectare of chili land. Farmers cannot afford to provide their own capital. Moreover, the risk of chili farming is quite high. Farid and Subekti (2012) stated that chili price fluctuations occur because chili production is seasonal, rainfall factors, production costs, and the length of distribution channels. For facing those difficulties, farmers decide to build partnership with middlemen. Capital loan social institutions in the middleman become social institutions that are quite unique and may not always be present in every region in Indonesia. 
Middleman is a term used by chili farmers to refer to middlemen who buy crops but also a person who has large capital and provides capital loans to farmers. Farmers get information from their relatives or neighbors or friends where they can get easy and interest-free farming capital.

Middleman who plays a role in Tegalweru chilli farming is MJ (Petungsewu) and MJD (UD Plasma Panen Unggul Genting Village). The trader came from outside the village but the village is still quite close to the farmers' village. Every farmer needs capital to chili farming. There are farmers who need to pay land rent to provide land for planting chili peppers. Farmers need money to work on the land and to buy chili seeds. Middleman usually lend in the form of farm production inputs such as fertilizers, pesticides, mulch and seeds as in one of the MJD farm shop owners (Genting Village).

The physical capital loan system for the farm is recorded in a special book by the farmer. After harvesting, the calculation of the yield is reduced by the total debt of the production input. This system has advantages for farmers because during Eid holidays farmers are usually get a gift or souvenir from the middleman.

However, the uniqueness of the middleman capital system is that the middleman is brave enough to take risks by providing large loans based on the element of trust (trust) as the social capital of the farmer's relationship with the middleman without a written agreement. Despite the fact, not all people may not be able to apply the trust social capital properly. As stated by Tittenburn (2013), the notion of trust, commonly regarded as a core of social capital leads to its culturalist interpretation whereby its real socio-economic underlying substratum is ignored, or at best downplayed.

Middleman records how much capital loans that has been taken by farmers. Farmers are not charged interest at the beginning of the loan. In addition, there are no special requirements that are required by the middleman. However, in the process of partnership there is an unwritten agreement that farmers are required to sell their crops to the middleman. This will certainly affect the market price offered by the middlemen who give the average price below the market price. However, farmers are given the easier loan capital farming and market certainty in selling their products. Sometimes the middleman also lends money for certain needs of farmers if there is something urgent. Therefore the system of social capital institutions from middleman as a social institution was born due to the financial needs of farmers.

The system of buying and selling farmers with chili middleman is different from the system of buying and selling in general. Middleman will take the crops, weigh it and bring it first to be sold and then the money handed over to farmers. So it is not the "yarnen" system (pay after harvest) that is applied but the payment after the commodity is sold but is usually given some money from the commodity harvest. Middleman has more power because he has provided capital for chilli farming. The agreement is not written directly but only a written record of how much the commodity was brought and the capital that had been taken from the middleman. The amount has been paid is the remainder of the sale of the crops minus the borrowed capital. The existence of middleman makes farmers are actually facilitated by the availability of markets that are ready to buy farmers' crops. Therefore, the social institution from this system was born from the needs of the agricultural market.

Marketing of chilli commodities in Tegalweru Village in partnership with the middleman it is known that market certainty is more promising. As explained before, that chili farmers prefer partners with the middleman rather than ordinary middlemen because of market certainty so that the product will be sold directly in the harvesting time even though a price is determined by the middleman because it is a consequence of interest-free capital. Chili commodity has a very fluctuating price even it changes every day and it becomes the reason for farmers to sell their products to the middleman because the middleman always buy the crops even though the price is fluctuating.

If farmers experience crop failure, the middleman does not force the farmer to be able to return the loaned capital right then. The economic behavior exists without realizing it in every economic activity carried out by chilli farmers and middleman as partners in client patron. According to Popkin (1986) client patron relationship in the community are 
considered as a form of harmonious relationship to safeguard the interests of poor farmers according to moral economy. However, the reality of the relationship is characterized by exploitative relationships. The relationship actually more beneficial to the patron than the client. The resources invested by patrons turned out not only to improve client security and subsistence, but also to keep the good relationship and preserve farmers' skills that could change the balance of power.

\section{CONCLUSION}

The result showed that there is institutional system in the farming community, namely the wage system, land rent, partnership with farmers in capital and buying and selling of crops. Tegalweru Village Farmer Wage Institution System tends to use a daily wage system for payment of labor on the land. Land leasing system for farmers is implemented for those who do not own land because the middleman provides land. The partnership system between farmers and middleman is a pattern of agribusiness operational cooperation (KOA). Farmers get financial capital for farming from the middleman in the form of cash capital or other farming production inputs. The farmer partner system and the middleman apply a nonpayment system of harvest or according to the agreement between the middleman and the farmer. Both of them are waiting for the crop is sold first then a calculation is made with the prior farmer's debt to pay the end result and it is considered mutually beneficial. In fact, the middleman "juragan" still defined by the village community as an institution that provides more accessible capital for financial sustainability of the farm. The government can support increasing financial access for agriculture.

\section{REFERENCES}

1. BPS. (2018). The Result of Inter Census Agriculture Survey 2018. BPS Statistics Indonesia ISBN: 978-602-438-255-1.

2. De Cunzo, Lu Ann. (2004). A Historical Archaeology of Delaware: People, Contexts, And The Cultures Of Agriculture. Univ. Of Tennessee Press. Knoxville.

3. Farid, M. and N.A. Subekti. (2012). Tinjauan terhadap produksi, konsumsi, distribusi and dinamika harga cabe di Indonesia. Buletin Ilmiah Litbang Perdagangan 6(2): 211-233.

4. Ferrol-Schulte, D.,FerseS.C.A., Glaser, M. (2014). Patron Client Relationships, Livelihood and Natural Resources Management in Tropical Coastal Communities. Ocean and Coastal Management, Vol.100, pp. 63-73.

5. Hardono, Gatoet Sroe and Mewa, Aladin Nasution. (1992). Analisis Perkembangan Sewa Menyewa Lahan Di Pedesaan Lampung. Pusat Penelitian Sosial Ekonomi Pertanian. Bogor. Vol 9, No 2-1 (1992).

6. Miles, M.B, Huberman, A.M. (2014). Analisis Data Kualitatif. Terjemahan Tjetjep Rohindi Rohidi. UI-Press. Jakarta.

7. Moleong, Lexy J. (2016). Metodologi Penelitian Kualitatif. Remaja Rosdakarya. Bandung.

8. Planck, Ulrich. (1993). Sosiologi Pertanian. Jakarta: Yayasan Obor Indonesia.

9. Plano Clark, V. L., \& Creswell, J. W. (2015). Understanding Research: A Consumer's Guide. https://doi.org/13-978-0-13-158389-4. New Jersey.

10. Popkin, Samuel L.(1986).Petani Rasional.Yayasan Padamu Negeri. Jakarta.

11. Rustinsyah. (2011). Hubungan Patron-Klien di Kalangan Petani Desa Kebonrejo. Volume 24, Nomor 2. DepartemenAntropologi, FISIP, Universitas Airlangga. Surabaya.

12. Saptana and Ashari. (2007). Pembangunan pertanian berkelanjutan melalui kemitraan usaha. Jurnal Penelitian and Pengembangan Pertanian 26(4): 123-130.

13. Soukup, Marek. (2016). The Concept of Social Institution. Masaryk University, Faculty of Economics and Administration. Brno.

14. Sudarta, W. (2016). SosiologiPertanian. 1st ed. Udayana University Press. Denpasar.

15. Sukirno, Sadono. (2005). Mikro Ekonomi. Rajagrafindo Persada. Jakarta. 
16. Susanti, Anik, et al. (2013). Structure Of Agricultural Land Tenure And Labor Relation On Tengger Community (Study In Kradjan Hamlet, Sapikerep Village, Upper Region Tengger Mountain). Habitat Volume XXIV No. 1 Bulan April 2013 ISSN: 0853-5167.

17. Susilowati, Sri Hery. (2016). Farmers Aging Phenomenon and Reduction in Young Labor: Its Implication for Agricultural Development. Forum Penelitian Agro Ekonomi, Vol. 34 No. 1, Juli 2016: 35-55.

18. Syaputra, Ary and Jonhyanis. (2018). Hubungan Sosial Patron Klien Antara Tauke Sawit and PetaniSawit Di Desa Menggala Teladan kecamatan Tanah Putih Kabupaten Rokan Hilir. Jom Fisip Vol. 5 No. 1 - April 2018.

19. Sytch, Maxim and Yong Hyun Kim. (2013). Embeddedness. In D. Teece and M. Augier (Eds.), Palgrave Encyclopedia of Strategic Management.

20. Titternburn, Jacek. (2013). Social Capital. Trust and Ideology. European Journal of Interdisciplinary Studies. Vol. 5 Issue 12013. 